[Bull. Agr. Chem. Soc. Japan, Vol. 21, No. 3, p. 137 142, 1957]

\title{
Studies on Osmophilic Yeasts
}

\section{Part I. Salt-tolerance and Sugar-tolerance of Osmophilic Soy-yeasts}

\author{
By Hiroshi ŌNIsHI \\ Noda Institute for Scientific Research \\ Received November 15, 1956
}

\begin{abstract}
The characteristic of salt-tolerance of the osmophilic soy yeasts was different from their sugar-tolerance in the points of viability of the individual cells in a high concentration of salts or sugars of the same osmotic pressure, and of the limiting osmotic pressure for their growth. It became much more apparent that growth of the osmophilic yeasts in the medium of a high concentration of sodium chloride involved a process of physiological adaptation. The order of the toxicity of the salts for the growth of Zygosaccharomyces major was as follows: $\mathrm{K}^{+}<\mathrm{Na}^{+}<\mathrm{Mg}^{++}<\mathrm{Ca}^{++}<\mathrm{Li}^{+} \quad \mathrm{Cl}-<\mathrm{SO}_{4}^{+--} \div \mathrm{NO}_{3}^{-}$
\end{abstract}

In the previous report'1, it was found that in the viable counts of the yeasts grown in soy sauce mashes, which differed significantly from other brewage mashes in their high contents of sodium chloride $(\mathrm{NaCl} 18 \%)$ and nitrogenous compounds (as total N, $1.0 \sim 1.5 \%$ ), a remarkable fall was observed in a single step transplantation when ordinary $\mathrm{NaCl}$-free media were used for plating count, while there was not any significant fall to be observed when media containing sodium chloride in the same concentrations as soy sauce mashes were used, and also a fall in viability was similarly observed when, in a reverse direction, these yeasts grown in the plain medium $(\mathrm{NaCl} 0 \%)$ were directly transferred to the saline medium (NaCl 18\%). Since the osmophilic property of soy yeasts against sodium chloride could be increased by culturing in media containing sodium chloride, the author has regarded this, to a certain extent, as an adaptive nature, though this property had hitherto been simply believed to be genetically constant and transmissible.

From the above facts, it seemed that fundamental studies on the influences of sodium chloride on growth and metabolism

(1) H. Onishi, J. Agr. Chem Soc. Japan, 28, 546 (1954!. of the osmophilic yeasts should be carried on further, and elucidation of these studies might be of great interest in the manufacture of soy sauce and miso paste, and furthermore in the preservation of salted food.

In this paper, the characteristics of salttolerance and sugar-tolerance of osmophilic soy yeasts are shown.

\section{EXPERIMENTAL}

(1) Reversibility of Salt-tolerance of Osmophilic Soy Yeasts. The stability of $\mathrm{NaCl}$-tolerance which was acquired by growing in a medium containing sodium chloride was examined. Three strains of soy yeasts, Zygosaccharomyces major, N 5 and $\mathrm{N} 8$ were cultured successively in $\mathrm{NaCl}$-free and $\mathrm{NaCl} 18 \%$ koji extract media on the schedule shown in Table $I$. The salt-tolerance of the yeast cells grown in each cultural environment was measured by plating them on $\mathrm{NaCl}$ free and $\mathrm{NaCl} 18 \%$ koji extract agar. As shown in Table I, salt- tolerance which was acquired by the yeast cells grown in a $\mathrm{NaCl} 18 \%$ medium, was easily lost if these yeasts were once cultured in a $\mathrm{NaCl}$-free medium. Accordingly, even in case of the osmophilic yeasts, salt-tolernance was found to be much dependable on their cultural conditions, i.e. the presence and absence of $\mathrm{NaCl}$.

(2) Growth of Soy Yeasts on Various Media of Different Concentrations of Sodium Chloride. As shown in Table II, when the yeasts cultured in 


\section{TABLE I}

REVERSIBILITY OF SALT-TOLERANCE OF OSMOPHILIC YEASTS DEPENDING UPON THEIR CULTURAL ENVIRONMENTS

Cultural sequence: (Liquid culture in koji extract)

$\mathrm{NaCl} 0 \% \longrightarrow \mathrm{NaCl} 18 \%$
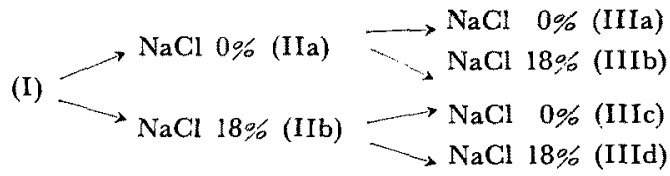

\begin{tabular}{|c|c|c|c|c|c|c|c|c|}
\hline \multirow{2}{*}{ Strains } & \multirow{2}{*}{$\begin{array}{l}\text { NaCl \% of } \\
\text { plating } \\
\text { media }\end{array}$} & & \multicolumn{6}{|c|}{ Cultural environments } \\
\hline & & I & IIa & IIb & IIIa & III b & IIIc & IIId \\
\hline Z. major & $\begin{array}{r}0 \\
18\end{array}$ & $\begin{array}{c}80^{*} \\
1456\end{array}$ & $\begin{array}{r}396 \\
10\end{array}$ & $\begin{array}{r}3 \\
952\end{array}$ & $\begin{array}{r}572 \\
45\end{array}$ & $\begin{array}{r}33 \\
250\end{array}$ & $\begin{array}{r}352 \\
35\end{array}$ & $\begin{array}{r}82 \\
248\end{array}$ \\
\hline N 8 & $\begin{array}{r}0 \\
18\end{array}$ & $\begin{array}{r}110 \\
1310\end{array}$ & $\begin{array}{l}96 \\
18\end{array}$ & $\begin{array}{r}53 \\
976\end{array}$ & $\begin{array}{r}472 \\
62\end{array}$ & $\begin{array}{r}35 \\
169\end{array}$ & $\begin{array}{r}528 \\
90\end{array}$ & $\begin{array}{r}32 \\
676\end{array}$ \\
\hline N 5 & $\begin{array}{r}0 \\
18\end{array}$ & $\begin{array}{r}15 \\
816\end{array}$ & $\begin{array}{r}152 \\
10\end{array}$ & $\begin{array}{r}9 \\
412\end{array}$ & $\begin{array}{r}508 \\
20\end{array}$ & $\begin{array}{r}155 \\
1778\end{array}$ & $\begin{array}{r}712 \\
71\end{array}$ & $\begin{array}{r}162 \\
1704\end{array}$ \\
\hline
\end{tabular}

* These values indicate the number of colonies on each plate.

TABLE II

Change in Viability of Yeast Gells When Transferred from a NaCl-Free MEDIUM TO MEDIa OF VARIOUS CONCENTRATIONS OF NaCl

\begin{tabular}{lccccc} 
Strains & \multicolumn{5}{c}{$\mathrm{NaCl} \%$ of Plating media (koji extract agar) } \\
\cline { 2 - 6 } Z. major & $0 \%$ 5\% & $5 \%$ & $10 \%$ & $15 \%$ & $18 \%$ \\
Z. soya & 936 & 912 & 728 & 372 & 108 \\
A 31 & 284 & 260 & 194 & 24 & 5 \\
A 34 & 538 & 508 & 436 & 276 & 170 \\
N 5 & 158 & 173 & 166 & 71 & 31 \\
N 8 & 140 & 154 & 149 & 49 & 14 \\
N 15 & 342 & 376 & 286 & 123 & 35 \\
N 21 & 310 & 290 & 266 & 72 & 21 \\
N 24 & 340 & 340 & 364 & 248 & 70 \\
N 28 & 928 & 896 & 880 & 728 & 404 \\
Tested strajos were isolaed from soy sauce mashes and showed high salt-tolerance, &
\end{tabular}

TABLE III

Change in Viability of Yeast Gells When Transferred From NaCl $5 \%$ To $\mathrm{NaCl} 18 \%$ MEDIUM

\begin{tabular}{|c|c|c|c|c|c|}
\hline \multirow[t]{2}{*}{ Strains } & $\mathrm{NaCl} \%$ of & medium & Strains & $\mathrm{NaCl}$ & \multirow{2}{*}{$\begin{array}{c}\text { medinm } \\
-18 \%\end{array}$} \\
\hline & $5 \%$ & $18 \%$ & & $5 \%$ & \\
\hline Z. major & 2192 & 1584 & N 8 & 856 & 812 \\
\hline$Z$. soya & 404 & 364 & N 15 & 968 & 712 \\
\hline A 31 & 1704 & 1480 & N 21 & 1872 & 1832 \\
\hline A 34 & 808 & 760 & N 24 & 776 & 800 \\
\hline N 5 & 1352 & 1168 & N 28 & 584 & 546 \\
\hline
\end{tabular}

$\mathrm{NaCl}$-free medium were transferred in a single step to the media of various $\mathrm{NaCl}$ concentrations, the fall in viability was very small up to $10 \%$ but remarkable above $15 \%$ of $\mathrm{NaCl}$ in the medium.
It is noteworthy that when the yeasts cultured in the medium of relatively low concentrations such as $5 \%$ of $\mathrm{NaCl}$ were transferred to the $\mathrm{NaCl} \mathrm{18 \%}$ medium, the fall in viability was remarkably small. 


\section{(Table III)}

The growth curve in the $\mathrm{NaCl} 18 \%$ medium, manifested by $Z$. major which was precultured in the media of different $\mathrm{NaCl}$ concentrations as $0,5,10$ and $18 \%$ is shown in Fig. 1.

The composition of the liquid medium employed

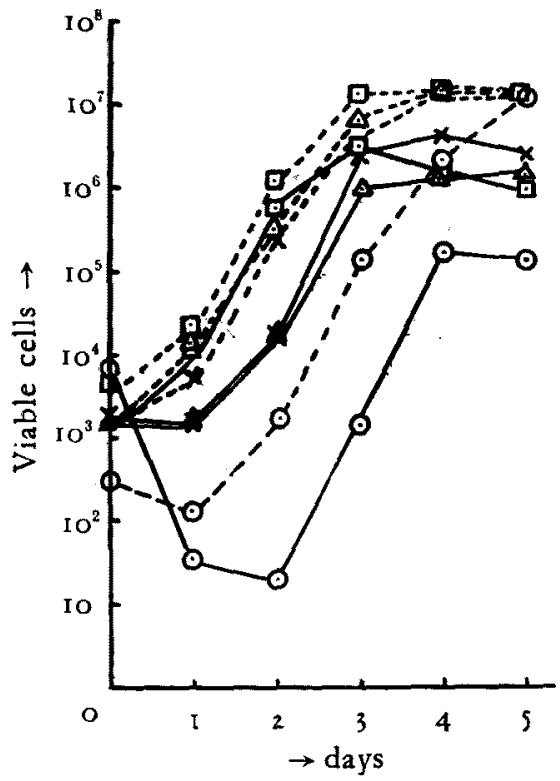

FIG. 1. The Effects of the Precultural Conditions on the Growth of $Z$. major in NaCl 18\% Medium.

$$
\begin{aligned}
& \mathrm{O}: \text { precultured in } \mathrm{NaCl}-\text { free medium } \\
& x: \text { precultured in } \mathrm{NaCl} 5 \% \text { medium } \\
& \triangle: \text { precultured in } \mathrm{NaCl} 10 \% \text { medium } \\
& \square: \text { precultured in } \mathrm{NaCl} 18 \% \text { medium } \\
& \text { solid line: plating on } \mathrm{NaCl} \text {-free medium } \\
& \text { broken line: plating on } \mathrm{NaCl} 18 \% \text { medium }
\end{aligned}
$$

was as follows: glucose $5 \% ; \mathrm{KH}_{2} \mathrm{PO}_{4} 0.1 \% ; \mathrm{MgSO}_{4}$. $7 \mathrm{H}_{2} \mathrm{O} 0.05 \% ; \mathrm{CaCl}_{2} \cdot 2 \mathrm{H}_{2} \mathrm{O} \quad 0.01 \% ; \mathrm{NaCl} 0.01 \%$; Bacto vitamin-free casamino acid $0.03 \%$ as total nitrogen; Bacto yeast extract $0.2 \%$; thereto $\mathrm{NaCl}$ was added to the required amount.

The growth of yeast was measured by a plating count using $\mathrm{NaCl}$-free and $\mathrm{NaCl} 18 \%$ media.

As shown in Fig. 1, when yeasts precultured in the medium containing more than $5 \% \mathrm{NaCl}$ were inoculated in the $\mathrm{NaCl} \mathrm{18 \%} \mathrm{medium,} \mathrm{the} \mathrm{fall} \mathrm{in} \mathrm{viability} \mathrm{at} \mathrm{the}$ lag phase of growth was not observed, but when precultured in the $\mathrm{NaCl}$-free medium, the fall in viability at the beginning of the growth curve was remarkable.

From these facts, it became much more clear that the growth of osmophilic yeasts in the medium of a high concentration of sodium chloride involves a process of physiological adaptation, this not merely being a recovery of yeast cells from the osmotic effects produced by sodium chloride.

(3) Limiting Osmotic Pressure for the Growth of Various Yeasts. Limit concentrations of sodium chloride and sugars for the growth of ordinary yeasts such as Saccharomyces saké and Sacch. ellipsoideus were found to be $10 \%$ in $\mathrm{NaCl}, 50 \%$ in glucose and $60 \%$ in saccharose, and for osmophilic yeasts, such as Zygosaccharomyces major and Zygosacch. soya were 20 $22 \%$ in $\mathrm{NaCl}, 80 \%$ in glucose and $80 \%$ in saccharose, respectively.

Osmotic pressure of the medium was calculated from the formula of Lewis²).

$$
\mathrm{II}=12.06 \Delta-0.021 \Delta^{2}
$$

where

II : osmotic pressure (atm.)

$\Delta:$ degree of freezing point depression $\left({ }^{\circ} \mathrm{C}\right)$

Values for freezing point depression of $\mathrm{NaCl}$ solution were taken from the Table of Landolt-Börnstein ${ }^{3)}$. Published data on these measurements by Frazer and Myrick $^{4)}$, Church ${ }^{53}$ and International Critical Tables vol. 4 were also referred.

Limiting osmotic pressure for their growth was, therefore, calculated as 75 atm. in $\mathrm{NaCl}, 140 \mathrm{~atm}$. in glucose and $90 \mathrm{~atm}$. in saccharose for Sacch. sake and Sacch. ellipsoidius, and 150 165 atm. in $\mathrm{NaCl}$, $220 \sim 260$ atm. in glucose and $180 \sim 200$ atm. in saccharose for Zygosacch. major and Zygosacch. soya.

It seemed quite natural that the soy yeasts, as a group of the so-called osmophilic yeasts show as above, much higher tolerance towards a high osmotic pressure than the ordinary yeasts; it was also noticeable that in general, the osmotic pressure which limits growth of the yeasts is much lower in $\mathrm{NaCl}$ than in sugar.

(4) The Growth of Soy Yeasts on the Media of High Concentrations of Sugar. Sugar concentration which corresponds to the osmotic pressure of a $18 \% \mathrm{NaCl}$ solution (135 atm.) is $50 \%$ in glucose, $75 \%$ in saccharose and $50 \%$ in galactose respectively. Though a fall in viability was, as above-stated, very remarkable when soy yeasts culcured in $\mathrm{NaCl}$-free

2) G.N. Lewis, J.Am. Cbem. Sor. 30, 668 (1908).

3) Landolt-Börastein, Pbylikalisch-Cbemische Tobellen 2, 1452 (1923).

4) J.C.W. Frazer and R.T. Myrick, J.Am. Cbem. Soc. 38, 1907 (1916).

5) M.B. Church, Science, 74, 492 (1931). 
TABLE IV

Changes in Viability of YeAst Cells Transferred FROM THE Plain Medium To Media of High Sugar Concentrations

$\begin{array}{lcccccc}\text { Strains } & \text { koji-agar } & \begin{array}{c}\text { glucose 50\% } \\ \text { koji-agar }\end{array} & \text { koji-agar } & \begin{array}{c}\text { saccharose } \\ \text { koji-agar }\end{array} & \text { koji-agar } & \begin{array}{c}\text { galactose } \\ \text { koji-agar }\end{array} \\ \text { Z. major } & 532 & 524 & 468 & 460 & 1512 & 1496 \\ \text { Z. soya } & 292 & 302 & 304 & 328 & 832 & 800 \\ \text { A 31 } & 486 & 464 & 1232 & 1304 & 1600 & 1632 \\ \text { A } 34 & 132 & 144 & 176 & 182 & 456 & 460 \\ \text { N } 5 & 352 & 332 & 660 & 688 & 1000 & 896 \\ \text { N } 8 & 364 & 366 & 560 & 564 & 828 & 828 \\ \text { N } 15 & 115 & 122 & 772 & 832 & 400 & 444 \\ \text { N } 21 & 544 & 536 & 532 & 568 & -26 & -1656 \\ \text { N } 24 & 342 & 308 & 1624 & 1560 & 206 & 202 \\ \text { N } 28 & 158 & 175 & 328 & 372 & & \end{array}$

medium werc transplanted into the $\mathrm{NaCl} 18 \% 6$ medium, it was examined whether a similar change in viability would really occur when in place of NaCl-medium, a sugar medium, whose osmotic pressure was adjusted

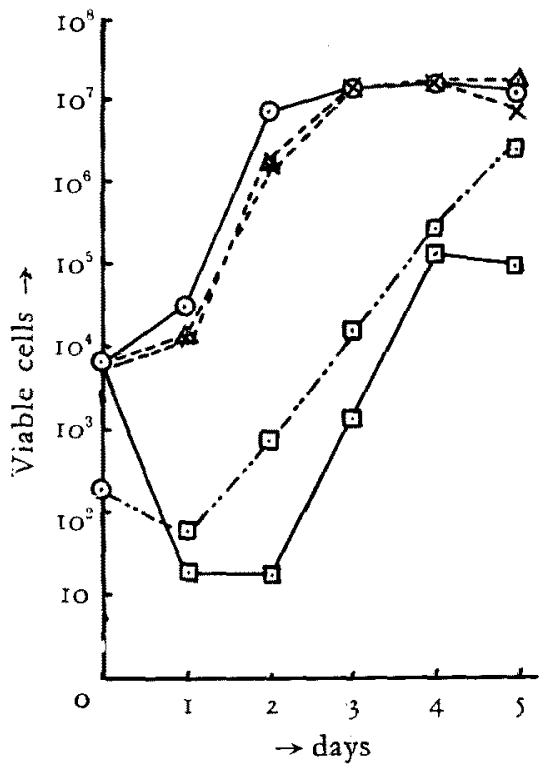

FIG. 2. Growth Curve of Z. major in the high Sugar Concentration Medium.

0 : inoculated into the basal plain medium

$x$ : inoculated into the glucose $50 \%$ medium

$\triangle:$ inoculated into the galactose $50 \%$ medium

$\square$; inoculated into the $\mathrm{NaCl} 18 \%$ medium plain koji agar

-....: glucose 50\% koji agar

-..-: $\mathrm{NaCl} 18 \%$ koji agar to be equal to that of a $18 \%$ ' $\mathrm{NaCl}$ solution was used. Unlike $\mathrm{NaCl}$, a fall in viability for the sugars was not observed as shown in Table IV. In this test, it cannot occur that sugar concentration of the medium may decrease significantly according to the growth of yeasts, because tested yeasts cannot ferment galactose and saccharose, but can only assimilate them very weakly ${ }^{6}$.

As shown in Fig. 2, when the yeasts cultured in the plain medium were inoculated directly into the basal plain, $18 \% \mathrm{NaCl}, 50 \%$ glucose or $50 \%$ galactose medium (the basal medium was the same as that shown in Fig. 1), not only in the basal plain medium but also in the glucose $50 \%$ and galactose $50 \%$ medium, the fall in viability at the lag phase of the growth curve was not found, but in $18 \% \mathrm{NaCl}$ medium, a remarkable fall in viability was observed at the initial stage of growth.

Now, it is apparent that characteristics of salttolerance and sugar-tolerance of the osmophilic soy yeasts toward the medium of the same osmotic pressure, are quite different from each other, so some limiting factors other than the osmotic pressure itself are presumable to have influence on the salt-tolerance of the osmophilic yeasts.

(5) Growth of Soy Yeasts in the Medium of a High Concentration of Various Salts. The growth of Zygosaccharomyces major in the liquid media of various concentrations of sodium sulfate, sodium nitrate, potassium chloride, lithium chloride, calcium chloride and magnesium sulfate was observed. The basal medium was the same as that shown in Figs. 1 and 2. The growth curve is shown

6) H. Onishi, This bullerin (in press). 

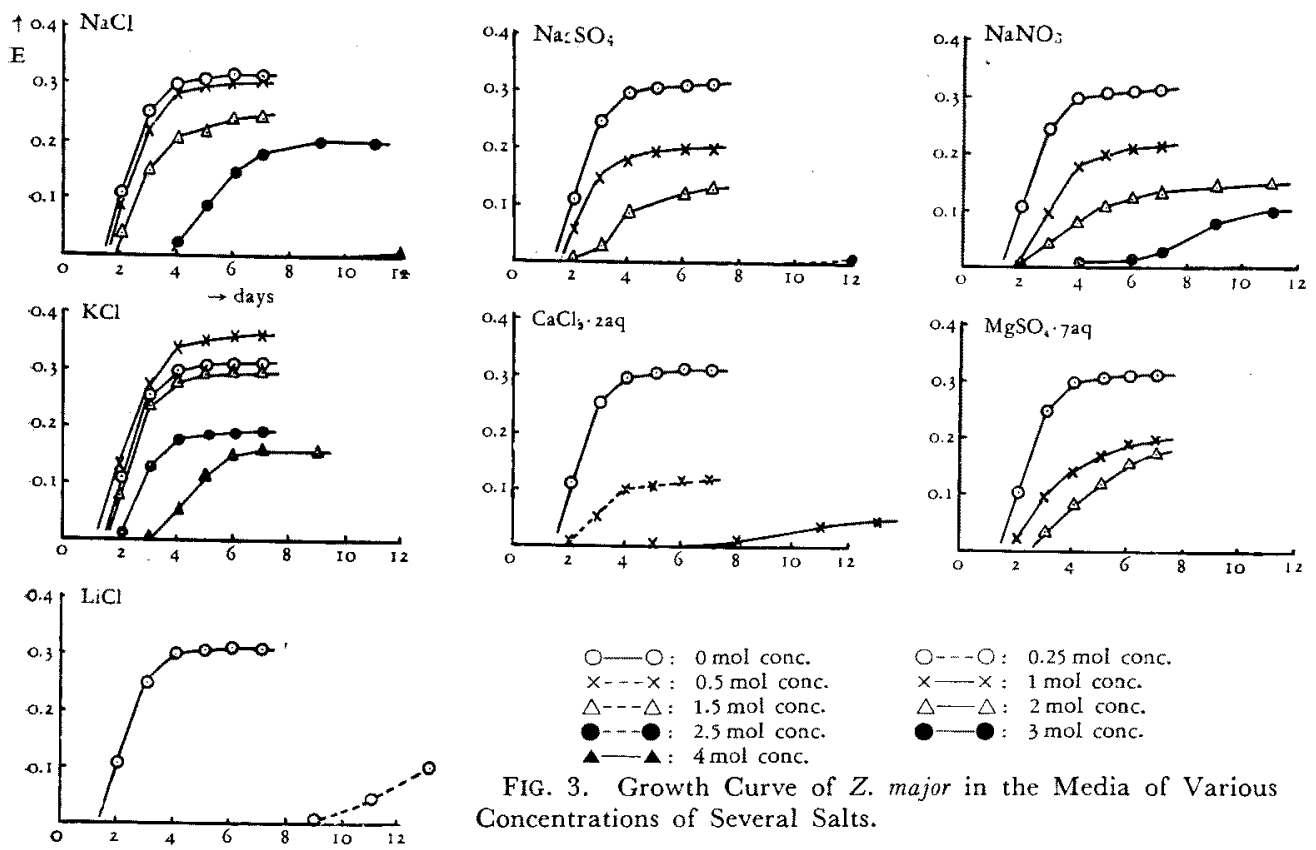

$$
\begin{aligned}
& 0-0: 0 \mathrm{~mol} \text { conc. } \\
& x-\cdots x: 0.5 \mathrm{~mol} \mathrm{conc} \\
& \triangle--\triangle: 1.5 \mathrm{~mol} \text { conc. } \\
& \text {-... : } 2.5 \mathrm{~mol} \mathrm{conc}
\end{aligned}
$$$$
\text { O- - }-0: 0.25 \mathrm{~mol} \text { conc. }
$$$$
x-\mathrm{x} \text { : } 1 \mathrm{~mol} \mathrm{conc} \text {. }
$$$$
\triangle-\triangle: 2 \mathrm{~mol} \text { conc. }
$$$$
\text { - } 3 \mathrm{~mol} \text { conc. }
$$

FIG. 3. Growth Curve of $Z$. major in the Media of Various Concentrations of Several Salts.
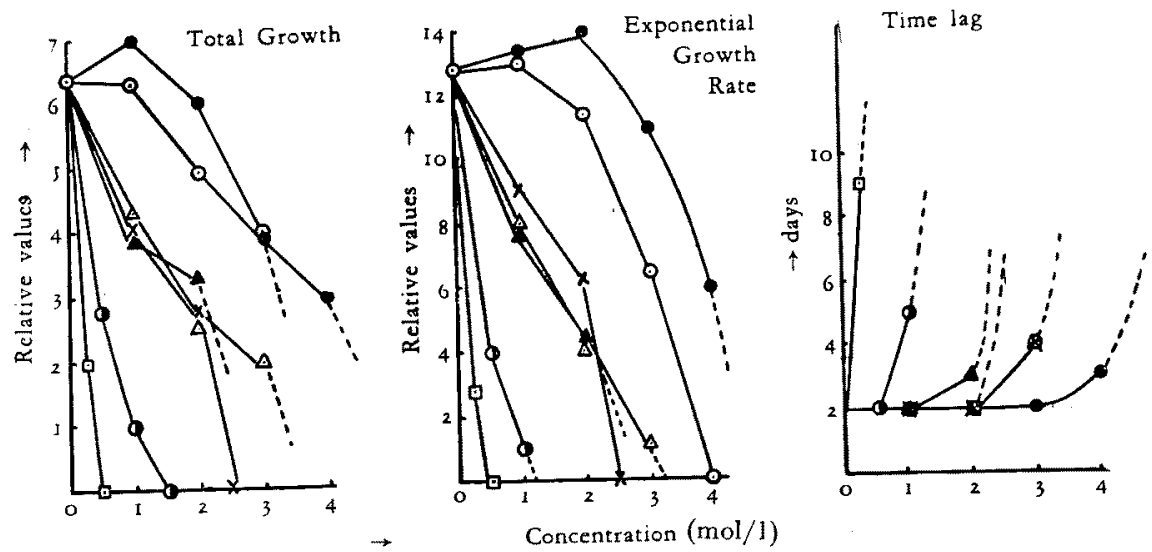

$0: \mathrm{NaCl}, \quad \times: \mathrm{Na}_{2} \mathrm{SO}_{4}, \quad \triangle: \mathrm{NaNO}_{3}$

A: $\mathrm{MgSO}_{4} \cdot 7 \mathrm{H}_{2} \mathrm{O}, \mathrm{O}: \mathrm{CaCl}_{2} \cdot 2 \mathrm{H}_{2} \mathrm{O}, \square: \mathrm{LiCl}$

FIG. 4. Relations between the Growth Gonstant and the Concentrations of Several Salts for the Growth of Z. major.

in Fig. 3.

Relations between the growth constant, e.g. total growth, exponential growth rate and time lag, and the concentrations of salts in the medium are shown in Fig. 4. For Zygosaccharomyces major, the order of toxicity of ions per molar concentration of the tested salts was as follows:

$\mathrm{K}^{+}<\mathrm{Na}^{+}<\mathrm{Mg}^{++}<\mathrm{Ca}^{++}<\mathrm{Li}^{+}, \quad \mathrm{Cl}^{-}<\mathrm{SO}_{4}^{--} \cdot \mathrm{NO}_{3}^{-}$

The growth of Zygosacch. mojor was inhibited by relatively low concentrations of $\mathrm{LiCl}$ such as $0.5 \mathrm{~mol}$ 
TABLE $V$

Fall in Viability of Yeast Gells Transferred from the Plain MEDIUM TO THE KCl 23\% MEDIUM

$\begin{array}{lcc}\text { Strains } & \text { koji agar } & \begin{array}{c}\text { KCl 23\% } \\ \text { koji agar }\end{array} \\ \text { Z. major } & 1072 & 139 \\ \text { Z. soya } & 172 & 62 \\ \text { A 31 } & 358 & 200 \\ \text { A } 34 & 312 & 145 \\ \text { N } 5 & 780 & 113\end{array}$

per l, while on the contrary, in the case of $\mathrm{KCl}$ the growth was very good even in such a high concentration as 4 mols per 1. $\mathrm{Mg}^{++}$was found less toxic than $\mathrm{Ca}^{++}$.

A fall in viability was also observed when yeasts cultured in a plain medium were transferred directly to the $\mathrm{KCl} 23$ \% molar concentration as $18 \% \% \mathrm{NaCl}$.

\section{SUMMARY}

(1) The salt-tolerance of soy yeasts acquired by growth in the saline medium with $\mathrm{NaCl}$ was easily lost if these yeasts were afterwards once cultured in the ordinary medium without $\mathrm{NaCl}$. Accordingly, in the case of osmophilic soy yeasts salt-tolerance was much dependable upon their cultural environments with or without $\mathrm{NaCl}$. Extreme salt-tolerance could be acquired even when the yeasts were cultured in the medium of $\mathrm{NaCl}$ of a relatively low concentration as $5 \%$. Thus it becomes quite apparent that the growth of osmophilic yeasts in the medium of a high concentration of $\mathrm{NaCl}$ involves the process of physiological adaptation.

(2) A fall in viability was not observed, contrary to the case of $\mathrm{NaCl}$, when the yeasts cultured in the plain medium were transferred directly to the medium consisting of a high concentration of sugars corresponding to the osmotic pressure of $18 \% \mathrm{NaCl}$ (135 atm.).

$\begin{array}{cc}\text { koji agar } & \begin{array}{c}\text { KGi } 23 \% \\ \text { koji agar }\end{array} \\ 153 & 9 \\ 744 & 96 \\ 524 & 100 \\ 960 & 99 \\ 287 & 119\end{array}$

The limiting osmotic pressure for their growth was higher in sugars $(220 \sim 260 \mathrm{~atm}$.) than in $\mathrm{NaCl}(150 \sim 165 \mathrm{~atm}$.$) .$

In these respects, the characteristic of the salt-tolerance of osmophilic soy yeasts differs. from that of their sugar-tolerance and it is. clear that some other limiting factors besides. the osmotic pressure itself, will have effect on their salt-tolerance.

(3) The viability of the yeast cells when transferred from the plain medium to the various salt media generally fell. Judging: from the relations between the growth constant and various concentrations of salts in the medium, the order of toxicity of the salts. for the growth of Zygosaccharomyces major was estimated as follows:

$$
\begin{aligned}
\mathrm{K}^{+}<\mathrm{Na}^{+}<\mathrm{Mg}^{++}<\mathrm{Ca}^{++}<\mathrm{Li}^{+}, \\
\mathrm{Cl}^{-}<\mathrm{SO}_{4}^{--} \fallingdotseq \mathrm{NO}_{3}{ }^{-}
\end{aligned}
$$

Acknowledgement I would like to express my sincerest thanks to Prof. K. Sakaguchi of University of Tokyo for his kind guidance and encouragement throughout this work. Great indebtness is also acknowledged to Prof. T. Asai and Prof. Y. Sumiki for their valuable suggestions. I also wish to thank to Dr. M. Mogi, the President of Noda Institute for Scientific Research for his encouragement. 